\title{
Histological Evaluation of the Induced Endometriosis in Rats, after Treatment with Dexamethasone
}

\author{
Evaluación Histológica de la Endometriosis Inducida en Ratas, \\ Posterior al Tratamiento con Dexametasona \\ "Ana Paula Castor Batista; *Ana Paula Maria da Conceição; "Eleonora de Figueiredo Moraes; \\ *Álvaro Aguiar Coelho Teixeira \& *Valéria Wanderley Teixeira
}

BATISTA, A. P. C.; CONCEIÇÃO, A. P. M.; MORAES, E. F.; TEIXEIRA, A. A. C. \& WANDERLEY-TEIXEIRA, V. Histological evaluation of the inducced endometriosis in rats, after treatment with dexamethasone. Int. J. Morphol., 24(4):565-570, 2006.

SUMMARY: The present research had the purpose to analyze morphologically the sites of endometrial implants on the external area of the musculature of the anterior abdominal wall of female rats, treated with dexamethasone. For so, these 15 albino female rats were used (Rattus norvegicus albinus), of the lineage Wistar with 90 days of age, that were submitted to the induction of the endometriosis, and divided in the following groups: Group I - induced female rats to endometriosis and evaluated after 21 days (control); Group II induced female rats to endometriosis and after 21 days, treated with dexamethasone for 10 days; Group III - induced female rats to endometriosis, and after 21 days, treated with dexamethasone for 15 days. The dexamethasone was administered in the dosage of $0,8 \mathrm{mg} /$ day/animal. Our results showed that the chronic inflammatory process in the endometriosis doesn't decrease after treatment with dexamethasone for 10 days, while the treatment with dexamethasone for 15 days reverted the chronic inflammatory process in the endometriosis, besides stimulating the proliferation of glands in endometrial implants.

KEY WORDS: Endometriosis; Dexamethasone; Steriods; Hormones; Metaplasia.

\section{INTRODUCTION}

It is known that in the uterus, the endometrium, dependant mucosa hormone, suffers clinical changes due to the action of ovarian sexual steroids, those being directly responsible for their proliferation (Noyes et al., 1950; Gambrell, 1976; Rodrigues de Lima et al., 1977; Alves de Lima, et al., 1979 and Baracat, 1991).

Under the action of the ovarian hormones (estrogen and progesterone) produced by the stimulus of the adenohypophysis, there are clinical structural changes in the endometrium that constitutes the menstrual cycle. During this cycle, the endometrium is constituted by two layers: functional and basal. The functional layer, the most superficial, is untied during the menstruation, while the basal layer is more slender and deep. It is kept during the cycle for the cells to proliferate and regenerate the functional layer in each menstrual cycle (Gartner \& Hiatt, 1999).

During the menstruation it may occur the elimination, through the uterine tubes, of viable endometrial material, which would have conditions of insertion, and consequently, originate a clinical picture named as endometriosis. This theory is reinforced by the presence of blood in the peritoneal cavity in the menstrual period (Sampson, 1921).

According to Tobias-Machado et al. (2001), there are several theories to explain the cause of the endometriosis, such as: transtubarian regurgitation of the menstrual material; celomic metaplasia; lymphatic or blood dissemination; immunological deficiency and genetic heritage. In the last years it has been verified an increase in the frequency of the endometriosis. This growth is due to changes in the habits of the females; increase of the first pregnancy age; higher interval between pregnancies, what promotes a longest period of time of estrogen exposition and a higher menstruation frequency (Tobias-Machado et al.).

In the estrous cycle of rats, as well as other animals, several phases of estrogen action are observed (proestrous and estrous) and of progesterone (metaestrous and diestrous). 
This way, several experimental models of endometriosis in rats (induced endometriosis), which histologically and endocrinologically reproduce this pathology have been elaborated, causing a better understanding about the physiological and biochemical aspect (Mori et al., 1998, Witz et al., 1999, Boucher et al. and Piva et al., 2001).

Studies have demonstrated that the glucocorticoids, among which the dexamethasone, inhibit the cellular proliferation and its effects can be observed in the reproductive functions because it blocks several induced responses by the estrogen in the uterus of rats (Szego \& Roberts, 1953; Szego \& Davis, 1969; Campbell, 1978 and Bigsby \& Cunha, 1988). However, Batista et al. (2004) report the administration of dexamethasone for five consecutive days in induced rats to the endometriosis was not enough to reduce the implant, suggesting that maybe the dosage or the period of the treatment have influenced in the result.

Thus the present research had the objective of evaluating, in rats, the histological aspects of the administration of the dexamethasone for 10 and 15 days consecutively, under the interaction of the endometrium and the skeletal grooved musculature of the abdominal cavity.

\section{MATERIAL AND METHOD}

The experiment was realized at the Laboratory of Area de Histology, of the Department of Morphology and Animal Physiology of the University Federal Rural de Pernambuco. Fifteen albino female rats (Rattus norvegicus albinus) were used, from the lineage Wistar and 90 days years old. The female were kept with meals and water ad libitum, in a temperature of $22^{\circ} \mathrm{C}$ and artificial illumination with fluorescent lamps (Philips), model daylight, 40W, which established the photoperiod for 12 hours clear and 12 hours dark, considering the period of light from 06:00 to 18:00h. The females were divided randomly, in three groups, each one constituted by five animals, namely: Group I - induced rats to endometriosis and evaluated after 21 days (control group); Group II - induced rats to endometriosis and treated after 21 days with dexamethasone for 10 days; Group III induced rats to endometriosis and treated after 21 with dexamethasone for 15 days. For the induction to endometriosis, it was used the technique of Vernon and Wilson (1985). For this procedure, the female were anesthetized with sulfate of antropine $(1 \mathrm{~mL})$, diluted in $1 \mathrm{~mL}$ of distilled water, being administered to $0,2 \mathrm{~mL}$ of the solution by intraperitoneal way. After that, $0,1 \mathrm{~mL}(20 \mathrm{mg} / \mathrm{mL})$ of xylazine and $0,1 \mathrm{~mL}$ of ketamine were administered, both by intraperitoneal way. Afterwards, by means of manual pulling, the trichotomy of the abdominal region was made. After these proceedings, the abdominal cavity was opened by longitudinal incision in the alba line of approximately $2 \mathrm{~cm}$ in order to identify the uterine horn. Once separated, nearly $1 \mathrm{~cm}$ from the half third of the right uterine horn was dissected and then the ligature of the vases proceeded. The uterine segment taken out was immediately immersed and physiological serum, longitudinally opened, and just then fragmented in two rectangles measuring approximately 4 to $5 \mathrm{~mm}$ of corner. These fragments were fixed with a nylon strand suture (6.0), in the external region of the musculature from the earlier wall of the abdominal cavity, one in each side of the alba line, always over the blood vessels, having the endometrium fraction in contact with the musculature. After all these procedures it was performed the suture in the abdominal cavity, and next, the skin.

After 21 days of the post-operatory (PO), was started the treatment with dexamethasone in the groups II and III. It was used the of dexamethasone dissodic phosphate (Decadron ${ }^{\circledR}$ ), to the concentration of $4 \mathrm{mg} / \mathrm{mL}$, being administered through intraperitoneal injections in a dosage of $0,2 \mathrm{~mL} /$ day/animal, in agreement with methodology described by Cruz et al. (1996). The implants were collected, fixated in Bouin liquid and embedding in paraplast.

\section{RESULTS}

In the animals of group I (control) the implants presented themselves totally adhered to the muscular layer (Fig.1), with a great amount of granulation tissue characterized by leucocitary infiltration. The glands presented themselves numerous enough, being arranged in groups in a spherical format, in their majority, covered by cubic simple epithelium, sometimes containing leucocytes in their lumen (Fig. 2).

The morphological analysis of the endometrial implants treated with dexamethasone for 10 days revealed that they were totally adhered to the abdominal musculature. In those implants it was observed the presence of extensive granulomas, constituted of a great quantity of macrophages, lymphocytes and gigantic cells of foreign body (Figs. 3 and 4).

In the endometrial implants of the animals treated for fifteen days, it was observed the relative adherence of them with the abdominal musculature. Histologically, these implants found themselves constituted by numerous glands, forming groups, separated by adipose tissue. It was not shown the presence of infiltrated leucocitary, granulation tissue and covering epithelium (Fig. 5). 


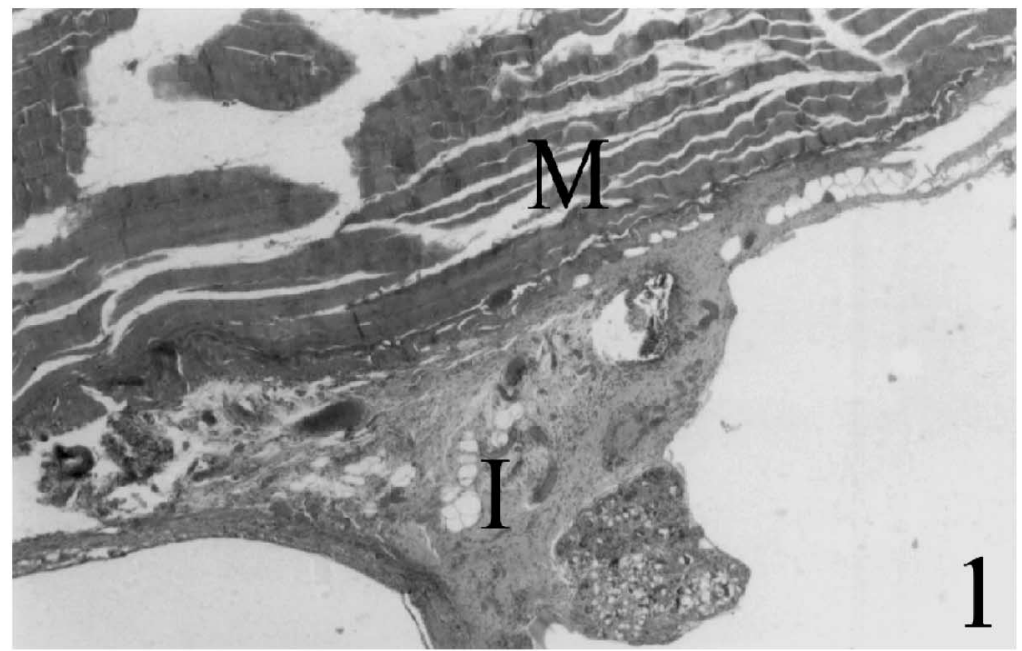

Fig. 1. Endometrial implant in rats from group I. Notice implant (I) totally adhered to the muscular layer (M). H.E. $\pm 107 X$.

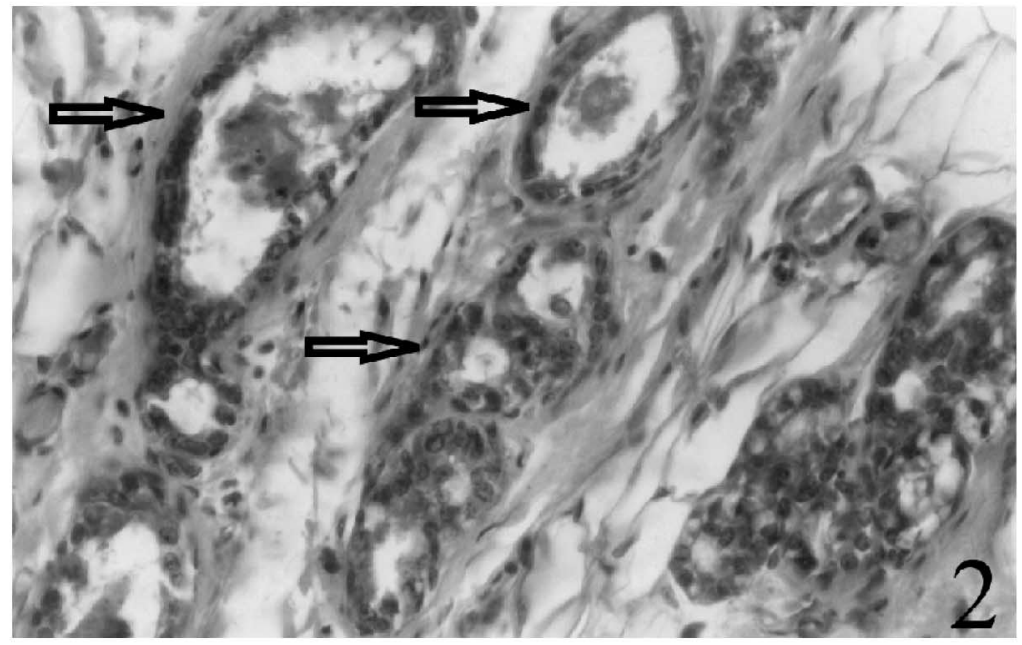

Fig. 2. Endometrial implant in rats from group I. Check great amount of glands (arrows). H.E. $\pm 428 X$.

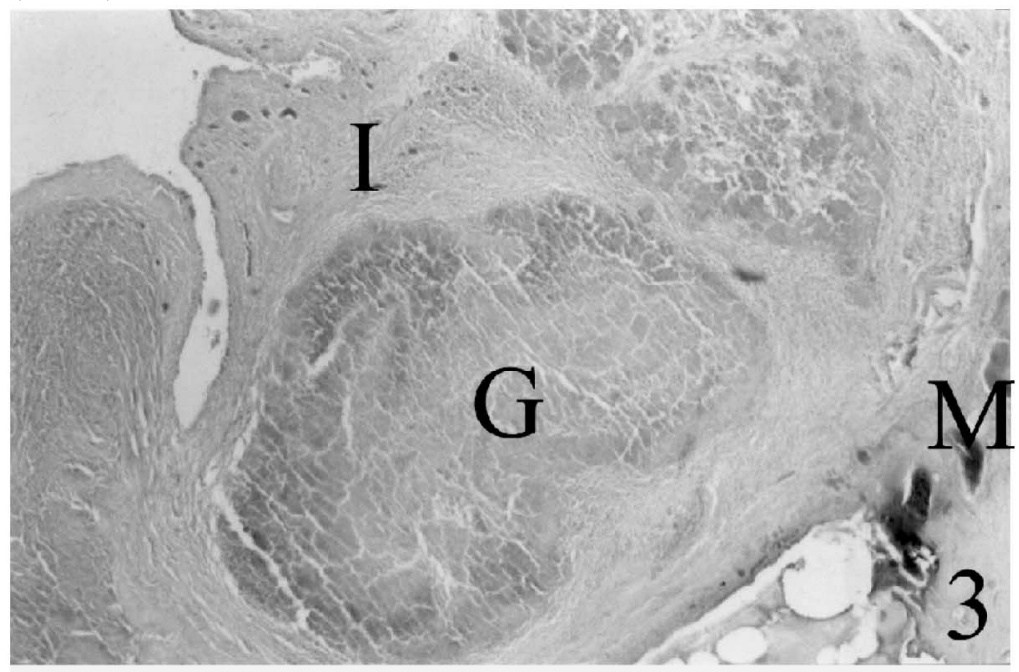

Fig. 3. Endometrial implant in rats from group II. Notice implant (I) totally adhered to the muscular layer (M), besides granulomas (G). H.E. $\pm 107 \mathrm{X}$.

\section{DISCUSSION}

The ectopic endometrial cells are similar to the normal endometrium, answering to the same hormonal stimulus although they have enzymatic activities receiving levels that differ in concentration and answer. It is still known that the estrogen stimulates the growth of the ectopic endometrial tissue because it is not found the endometriosis before the first menstruation, as well as after the menopause (Vyas \& Gangar, 1995).

In the group treated with dexamethasone for 10 days, it was observed in the implants the presence of granulation indicating the establishment of a chronic inflammatory process. It is known that one of the ways of establishing a chronic inflammatory process is when the tissue damage continues for a prolonged period of time, and in this case, the polymorphonuclear leucocytes are scarce or can be absent, predominating the elements called as mononuclear, such as macrophages and lymphocytes (Laguens, 1987; Benjamini, et al., 2002). According to Jolicoeur et al., (2001), due to the endometriosis be a chronic inflammatory process, it induces the increase of the macrophage numbers because the endometrial cells express the chemotactic factor of the monocytes (MCP-1), responsible for the grouping and activation of the macrophages.

Recent researches have demonstrated that treatments with dexamethasone in different concentrations show and inhibitory action, dose dependant, from the receiver MCP-1 expression, taking to a reduction of the endometrial process (Boucher, et al., 2000). Thus, the persistence of the chronic inflammation after ten days of treatment with dexamethasone can be also related to the concentration and/or period of administration of this substance.

The histological analysis of the implants in the animals from group III showed a great quantity of glands and the absence of any indication of the inflammatory process, 


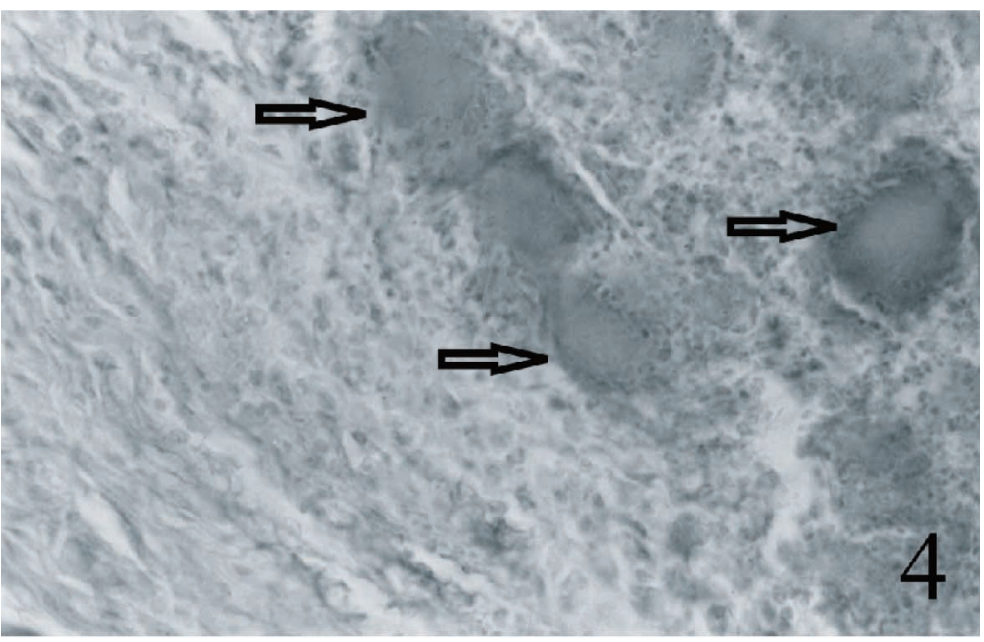

Fig. 4. Endometrial implant in rats from group II. Check foreign body giant cell (arrows). H.E. $\pm 428 X$.

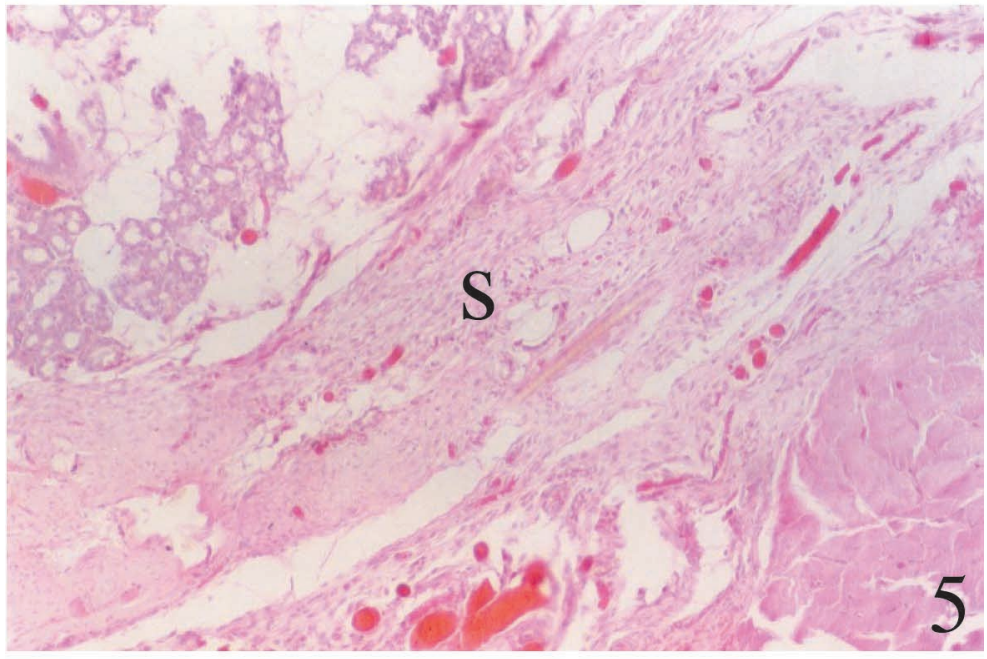

Fig. 5. Endometrial implant in rats from group III. Notice absence of leucocitary infiltrate and granulomas in the stroma (S). H. E. \pm 107 X.

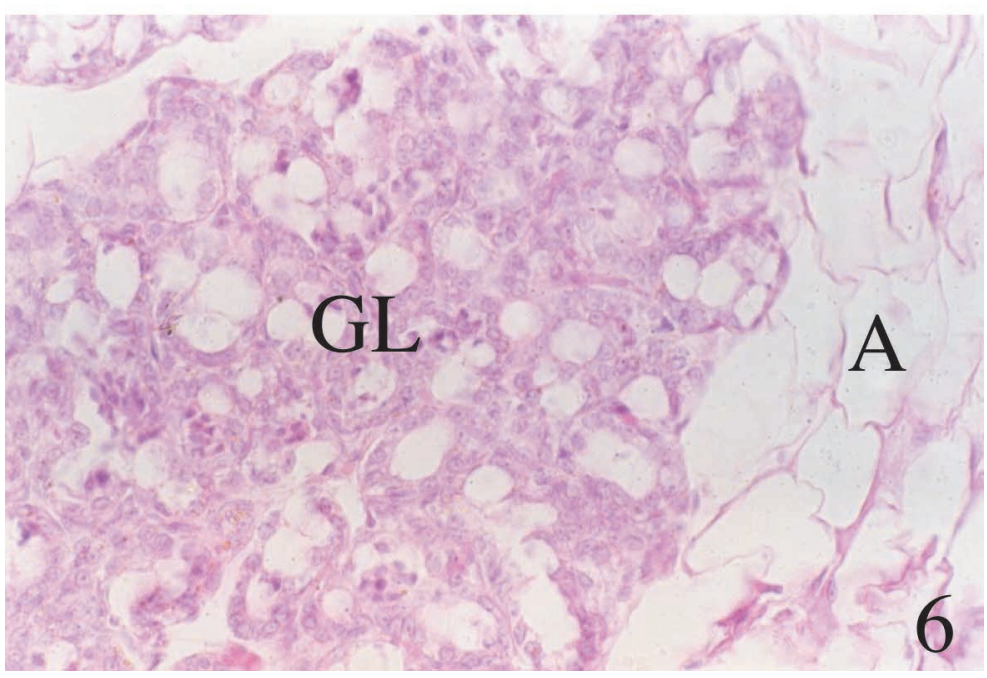

Fig. 6. Endometrial implant in rats from group III. Notice great amount of glands (GL) and adipose tissue (A). H. E. $\pm 107 X$. indicating a more effective action of the dexamethasone compared to the previous treatment. However, this treatment was not enough to inhibit the proliferation of endometrial glands in the implants. This is probably related to the presence of progesterone in these animals, because according to some authors, glucocorticoids, such as dexamethasone, present a stimulating action over the production of GnRH in the hypothalamus, resulting in the liberation of $\mathrm{LH}$, essential to the rupture of the ovarian follicles and formation of luteum bodies, causing the production of progesterone (Rosenfield et al., 1993; Arnhold et al., 1997; Rosenfield, 1999; De Geyter et al., 2002; Gentry et al., 2002).

BATISTA, A. P. C.; CONCEIÇÃO, A. P. M.; MORAES, E. F.; TEIXEIRA, A. A. C. \& WANDERLEY-TEIXEIRA, V. Evaluación histológica de la endometriosis inducida en ratas, posterior al tratamiento con dexametasona. Int. J. Morphol., 24(4):565-570, 2006.

RESUMEN: El objetivo de la investigación fue analizar morfológicamente los sitios de implantes endometriales sobre la región externa de la musculatura de la pared abdominal anterior de ratones, tratados con dexametasona. Para ello, fueron utilizados 15 ratones albinos (Rattus norvergicus albinus), del linaje Wistar, de 90 días de edad, los cuales fueron sometidos a inducción de la endometriosis y divididos en los siguientes grupos: Grupo I - ratones inducidos a la endometriosis y evaluados tras 21 días (control); Grupo II - ratones inducidos a la endometriosis y tras 21 días, tratados con dexametasona durante 10 días; Grupo III - ratones inducidos a la endometriosis, y tras 21 días, tratados con dexametasona durante 15 días. La dexametasona fue administrada en dosis de $0,8 \mathrm{mg} /$ día/animal. Nuestros resultados muestran que el proceso inflamatorio crónico en la endometriosis no baja después del tratamiento con dexametasona durante 10 días, mientras que el tratamiento con dexametasona durante 15 días cambió del proceso inflamatorio crónico en la endometriosis y estimuló la proliferación de glándulas en los implantes endometriales.

PALABRAS CLAVE: Endometriosis; Dexametasona; Esteroides; Hormonas; Metaplasia. 


\section{REFERENCES}

Alves de Lima, F. O.; Vasserman, J. \& Baract, E. C. Aspecto histológico do endométrio na pós-menopausa. J. Br. Ginecol., 84:303-10, 1979.

Arnhold, I. J.; Latronico, A. C.; Batista, M. C.; Carvalho, F. M.; Chrousosg, P. \& Mendonça, B. B. Ovarian resistance to luteinizing hormone a novel cause of amenorrhea an infertility. Fertil. Steril., 67 (2):394-7, 1997.

Baracat, E. C. Aspectos morfológicos e morfométricos do endométrio humano na pós-menopausa, antes e pós estrogenioterapia oral e transdérmica. São Paulo, 1991. [Tese de Livre-Docência - Escola Paulista de Medicina], $84 \mathrm{p}$.

Batista, A. P. C.; Conceição, A. P. M.; Gomes, J. P.; Simões, M. J.; Wanderley-Teixeira, V. \& Teixeira, A. A. C. Análise morfológica da ação da dexametasona sobre a endometriose induzida em ratas (Rattus norvegicus albinus). Arq. Inst. Biol., 71:427-9, 2004.

Benjamini, E.; Coico, R. \& Sunshine, G. Imunologia 4. ed. Rio de Janeiro, Guanabara Koogan, 2002. pp.13-4.

Bigsby, R. M. \& Cunha, G. R. Progesterone and dexamethasone inhibition of uterine epithelial proliferation in models of estrogen - independent growth. Am. J. Obst. and Gynecol., 158:646-50, 1988.

Boucher, A.; Lemay, A. \& Akoum, A. Effect of hormonal agents on monocyte chemotactic protein-1 expression by endometrial epithelial cells of women with endometriosis. Fertil. Steril., 74(5):969-75, 2000.

Campbell, P. S. The mechanism of the inhibition of uterotropic responses by acute dexamethasone pretreatment. Endocrinol., 103:716-23, 1978.

Cruz, F. C. M.; Smaniotto, S. \& Simões, M. J. Morphological aspects of the cervical mucosa of persistent estrous rats under action of estrogen and/or dexametasone. $\mathrm{Br} . \mathrm{J}$. Morphol. Scie., 13(1):100, 1996.

De Geyter, C.; De Geyter, M.; Huber, P. R.; Nieschlang, E. \& Holzgreve, N. Progesterone serum levels during the follicular phase of the menstrual cycle originate from crosstaek betweem the ovaries and the adrenal cortex. Hum. Reproducty, 17(4):933-9, 2002.

Gambrell, R. D. Estrogens, progestagens and endometrial cancer; In: Beard, R. J. Consensus on menopause research. Lancaster, MTP Press Ltd., 1976. pp. 152-3,

Gartner, L. P. \& Hiatt, J. L. Tratado de Histologia. $1^{\text {a }}$. ed. Rio de Janeiro: Guanabara Koogan, 1999. pp.365-9.

Gentry, L. R.; Thompson, D. L.; Gentry, G. T.; David, K. \& Godke, R. A. High versus low body condition in mares interactions with responses to somatotropin, $\mathrm{GnRH}$ analog, and dexamethasone. J. An. Scie. 80(12):3277$85,2002$.

Jolicoeur, C.; Lemay, A. \& Akoum, A. Comparative effect of danazol and a GnRH agonist on monocyte chemotactic protein-1 expression by endometriotic cells. Am. J. Reprod. Immunol., 45(2):86-93, 2001.

Laguens, R. P. Patologia. 1. ed. Montevideo, Inter-Médica, 1987. pp.264-6,

Mori, T.; Kyokuwa, M. \& Nagasawa, H. Animal model of uterine adenomyosis: induction of the lesion in rats by ectopic pituitary isografting. Lab. Anim. Sci. 48(1): 648, 1998.

Noyes, R. W.; Hertig, A. T. \& Rock, J. Dating the endometrial biopsy. Fertil. Steril., 1:3-25, 1950.

Piva, M.; Horowitz, G. M. \& Sharpe-Timms, K. L. Interleukin-6 differentially stimulates haptoglobin production by peritoneal and endometriotic cells in vitro: a model for endometrial-peritoneal interaction in endometriosis. J. Clin. Endocrinol. Metab., 86(6):2553$61,2001$.

Rodrigues de Lima, G.; Miyada, C. C.; Colombo, E.; Mattosinho França, L. C. \& Rodrigues Emilio, CL. Moléstia policística dos ovários associada a adenocarcinoma do endométrio. Rev. Paul. Med., 90:714, 1977.

Rosenfield, R. L.; Ehrman, D. A.; Barnes, R. B. \& Sheikh, Z. Gonadotrofin-releasing hormone agonist as a prole for the pathogeneses and diagnosis of ovarian hydrogenism. Acad. Scie., 687:163-81, 1993.

Rosenfield, R. L. Ovarian and adrenal function in polycystic ovary syndrome. Endocrinol Metab. Clin. North Am., 28(2):265-93, 1999. 
Sampson, J. A. Peforating hemorrhagic cysts of the ovary. Their importance and especially their relation to pelvic adenomas of the endometrial type (adenoma of the uterus, rectovaginal septum, sigmoid, etc. Arch. Surg., 3:245-323, 1921.

Szego, C. M. \& Roberts, S. Steroid action and interaction in uterine metabolism. Rec. Prog. Horm. Res., 8:419-69, 1953.

Szego, C. M. \& Davis, J. S. Inhibition of estrogen induced cyclic AMP elevation in rat uterus. II: By glucocorticoids. Life Scie., 8:1109-16, 1969.

Tobias-Machado, M.; Di Giuseppe, R.; Barbosa, C. P.; Borrelli, M. \& Wroclawski, E. R. Endometriose vesical: aspectos diagnósticos e terapêuticos. Rev. Assoc. Med. Bras., 47(1):37-40, 2001.

Vernon, M. W. \& Wilson, E. A. Studies on the surgical induction of endometriosis in the rat. Fertil. Steril., 44: 684-94, 1985.

Vyas, S. \& Gangar, K. Postmenopausal oestrogens and arteries. Br. J. Obstetric Gynecol., 102(12):942-6, 1995.

Witz, C. A.; Monotoya-Rodriguez, I. A. \& Schenken, R. S. Whole explants of peritoneum and endometrium: a novel model of the early endometriosis lesion. Fertil. Steril., 7(1):56-60, 1999.
Dirección para correspondencia: Prof. Dra. Valeria Wanderley Teixeira. Universidade Federal Rural de Pernambuco. Departamento de Morfologia e Fisiologia Animal. Área de Histologia

Rua Dom Manoel de Medeiros $s / n$ - Dois Irmãos CEP: $52.171-900$

Recife-PE

BRAZIL

Email:valeria@ufrpe.br

Received :19-05-2006

Accepted:09-09-2006 